\title{
Social Work and the Challenge of Entrepreneurship in Africa
}

\author{
Ani Casimir'1, Ejiofor Samuel² \\ ${ }^{1}$ Department of Philosophy, Institute of African Studies, Nsukka, Nigeria \\ ${ }^{2}$ Department of Social Work, University of Nigeria, Nsukka, Nigeria \\ Email: cepperngo@gmail.com, ejorsamchi@yahoo.com
}

Received 2 March 2015; accepted 20 March 2015; published 25 March 2015

Copyright (C) 2015 by authors and Scientific Research Publishing Inc.

This work is licensed under the Creative Commons Attribution International License (CC BY). http://creativecommons.org/licenses/by/4.0/

\section{Abstract}

One of the most difficult and challenging areas of research in social work practice is to create a philosophy of integration whereby some presumed assumptions are questioned and new areas of collaboration designed for best practices. It is the function of philosophy to question such assumptions and design newer areas of research for the practice in Africa. In this article, we have deigned to question the collaborative work of social work and entrepreneurship. This is what one might describe as the duty of the social innovator, social problem solver in business practices of the commonly defined deliverables from the social entrepreneur. In the social business innovator or entrepreneur, we have the best skills of the entrepreneurship, social philosophy, social work and social interested innovator. Many would have questioned the conjunction between the aggressive business entrepreneur who is profit oriented and the charity oriented non-governmental organizer who cares and works for others happiness. If both are for business and are investors, what kind of investment and profit is the social entrepreneur committed to in his business as different from the profit orientation of the business mogul. In Africa, such questioning and questions lead to a paradigm change in the popular understanding of the emerging area of the social entrepreneurship and the challenge of solving social problems of poverty and crisis in Africa. This article seeks to contribute to such social problem solving by enhancing the public awareness and education on the developmental possibilities of social entrepreneurship in Africa.

\section{Keywords}

Social Work, Social Entrepreneurship, Social Philosophy, Poverty, Innovation, Social Responsibility, Paradigm, Africa

\section{Introduction-Philosophy, Social Work and Social Entrepreneurship in Africa}

In the great work of social work and entrepreneurship, a lot of assumptions and questions are posed about con- 
cepts, ideas and programs of collaboration, cooperation and partnership. But what helps in bringing the two concepts together and clarifies the ideas in a critical way is philosophy as an analytical tool and social work as an experiential framework for solving the problems of the individuals in their in their social existence. What is exposed in the analysis is the fact that the social worker, the business man and the philosopher of humanitarian intervention are brought together by their interest to help the society to solve the existential social work problems of the society. There is what is called the business of living and solving the problems of living. Philosophy calls it social philosophy of the common good while social work profession calls it the business of welfare distribution or spreading hope. For the average business man or women in Africa, money invested should bring tangible and material gains or returns to the investor. He invests capital to have returns of capital but the social entrepreneur invests in peoples' lives what maybe capital or time or energy to solve their problems, to make them happy and generate humanitarian solutions to old existing problems.

The field of social entrepreneurship in Africa, though new, is growing and full of potential, but with little knowledge of what it could do to socially transform the African society in the $21^{\text {st }}$ century (ACARTSODA, 1983). This poor public knowledge is particularly unfortunate as this field seems to be bigger than Africa's past and with promises to add a higher standard of living to African welfare system. This explains why Author Giles Hutchins states, "It... seems that more and more people feel drawn into a career as a social entrepreneur." The field is increasingly being popularized but not as the general awareness of the renowned business entrepreneurs in Africa.

Unfortunately, in the mainstream business thinking in Africa, most people categorize social entrepreneurship as an odd assemblage so it has to overcome this significant social and popular barriers to the strong category boundaries most of African people like to insist upon such as "You're either a businessperson or a social worker-you can't be both.” So it is an African problem and secondly a social category issue globally not limited to Africa. Currently in Africa, whatever is special and innovative about the emerging social entrepreneurs tends to be viewed in Africa by Scholars as the thing which has never been done before but social entrepreneurs are gripped by their clear social motive to make a difference in the world, through innovative practices. The conventional thinking is that an entrepreneur would start something new and make good his money. Social work combines with traditional entrepreneurship to achieve social sustainability and not just profit for himself. Polsky (2013: p. 3) elaborates on this special combination and identifies some existing Entrepreneurs from the developing world:

For now, it is sufficient to see social entrepreneurs as innovators working at something in between a business and a social-welfare organization, perhaps in individual cases leaning more one way or the other. In short, according to Business Week, they "use business methods to solve social problems.” However, much more needs to be said about its definition, as the inherent ambiguity you might have noticed is both helping and, in its excess, unnecessarily hurting the field (hey, I usually like ambiguity). This will be discussed later in this series. (For the definition ally oriented, a particularly good one is by the Schwab Foundation for Social Entrepreneurship.) But looking ahead, the possibilities that social entrepreneurs can exist inside large companies that are pursuing (but not necessarily leaders yet) in sustainability does not even come up at forums. One example of social entrepreneurs is the famous pioneer of micro-finance, the Grameen Bank legion, led by Nobel laureate Muhammad Yunus (Moingeon, 2010: pp. 308-325), their great innovation was showing the conventional wisdom that poor, rural women were poor credit risks and could not be a viable market for banks' financial services was wrong, and developed a peer-based repayment model. Another is the prominent discoverer, financier, mentor and promoter of other social entrepreneurs, Ashoka.

However, it will be problematic to go further without getting to know the deeper meanings of the involved concepts such as entrepreneurship and social work. Fundamentally if we make enquiries about the meaning of social entrepreneurship we would have gotten the right perspectives of the great entrepreneurship fundamental questions and answers concerning "what is entrepreneurship”, "who is an entrepreneur”, "who is a social entrepreneur" and "what is social entrepreneurship”. From these fundamental questions and answers of entrepreneurship we should move to the fundamental questions and answers of social work and that of philosophy. We would not question the fundamentals but it is enough to go into the meanings of them in Africa to understand why and how the social worker, the philosopher of human values and the business entrepreneur would come together to make a paradigm shift and compress the fundamentals into an emergent enterprise model in a manner that would manifest the concept, power and impact of social entrepreneurship. Social entrepreneurship and the social entrepreneur, though not entirely new and not well established in Africa, have challenges that compel us in this article to question traditional assumptions and make worthwhile critique of some of its areas of practice. 
This is necessary because social entrepreneurs are social innovators who make things to happen in the social environment. One might want to call social entrepreneurs social workers who are into the big time social or business practice of social entrepreneurship. They bring new ways of solving old social problems or interpreting old social problems in a new way to generate innovation. They are philosophers of new ways of social philosophy and practice that help their society to interpret old challenges and problems and initiate new solutions and approaches in solving them. Africa needs social entrepreneurs and social philosophers of entrepreneurship so as to help Africa to solve some of its stubborn social crisis, conflicts, poverty and unemployment in a sustainable manner.

\section{Philosophical Elucidation and Foundations of Concepts Applied in Social Entrepreneurship-A Search for Meaning and Working Definition}

Philosophical elucidation will give an exposition of the meaning of the concept applied in social entrepreneurship and help us in getting to a working definition. To start with Matt Polsky (2013: p. 20) defines the social entrepreneur in the philosophical framework of business methods and processes used to transform society from poverty to wealth:

What is a Social Entrepreneur? Social entrepreneurs drive social innovation and transformation in various fields including education, health, environment and enterprise development. They pursue poverty alleviation goals with entrepreneurial zeal, business methods and the courage to innovate and overcome traditional practices. A social entrepreneur, similar to a business entrepreneur, builds strong and sustainable organizations, which are either set up as not-for-profits or companies. A social entrepreneur is a leader or pragmatic visionary who achieves large scale, systemic and sustainable social change through a new invention, a different approach, a more rigorous application of known technologies or strategies, or a combination of these; Focuses first and foremost on the social and/or ecological value creation and tries to optimize the financial value creation; Innovates by finding a new product, a new service, or a new approach to a social problem; Continuously refines and adapts approach in response to feedback; Combines the characteristics represented by Richard Branson and Mother Teresa; The Schwab Foundation employs the following criteria when looking for leading social entrepreneurs: Innovation, Sustainability, Reach and social impact. Polsky did not stop at the personal traits of the social entrepreneur but also went further to identify the social traits of the social entrepreneurs and described the philosophical constitution of what is a social entrepreneurship from the point of view of innovation, sustainability and social improvement in people's lives:

Social entrepreneurs share some come common traits including: An unwavering belief in the innate capacity of all people to contribute meaningfully to economic and social development; A driving passion to make that happen; A practical but innovative stance to a social problem, often using market principles and forces, coupled with dogged determination, that allows them to break away from constraints imposed by ideology or field of discipline, and pushes them to take risks that others wouldn't dare; A zeal to measure and monitor their impact. Entrepreneurs have high standards, particularly in relation to their own organization's efforts and in response to the communities with which they engage. Data, both quantitative and qualitative, are their key tools, guiding continuous feedback and improvement; A healthy impatience. Social Entrepreneurs cannot sit back and wait for change to happen-they are the change drivers.

Social entrepreneurship is therefore defined Polsky (2013: p. 3) as a term and process that:

Applying practical, innovative and sustainable approaches to benefit society in general, with an emphasis on those who are marginalized and poor; A term that captures a unique approach to economic and social problems, an approach that cuts across sectors and disciplines grounded in certain values and processes that are common to each social entrepreneur, independent of whether his/her area of focus has been education, health, welfare reform, human rights, workers' rights, environment, economic development, agriculture, etc., or whether the organizations they set up are non-profit or for-profit entities; It is this approach that sets the social entrepreneur apart from the rest of the crowd of well-meaning people and organizations who dedicate their lives to social improvement.

\section{Social Values, Social Enterprises-A Comparative Study of Global and African Models}

From the above, we could see that social entrepreneurship is about enterprise and Social enterprise has been de- 
fined as an organization that applies commercial strategies to maximize improvements in human and environmental well-being, rather than maximizing profits for external shareholders. Social enterprises can be structured as a for-profit or non-profit, and may take the form of a co-operative, mutual organization, a disregarded entity, a social business, or a charity organization. The term has a mixed and contested heritage due to its philanthropic roots in the United States, and cooperative roots in the United Kingdom, European Union and Asia. In the US, the term is associated with "doing charity by doing trade”, rather than "doing charity while doing trade". In other countries, there is a much stronger emphasis on community organizing, democratic control of capital and mutual principles, rather than philanthropy. In recent years, there has been a rise in the concept of social purpose businesses which pursue social responsibility directly, or raise funds for charitable projects. The idea of social enterprise has a long history around the world, though under different names and with different tendencies. Whilst many social enterprises will today accept finance and other forms of support from the state, they are essentially enterprises that seek independence from both the state and private capital through strategies that create a social economy. Early use of the terms "social enterprise" and "social entrepreneurship" can be traced to Beechwood College near Leeds, England (from 1978) where Freer Spreckley used the term social enterprise for worker and community co-operatives that used the "social accounting and audit" system developed at Beechwood, and at ASHOKA — a US foundation-during the 1980s where Bill Drayton established a program to support the development of social entrepreneurship.

Another formative influence was the Italian worker co-operatives who lobbied to secure legislation for "social co-operatives” in which members with mental or other health disabilities could work while fully recovering. The first academic paper to propose worker co-operatives involved in health and rehabilitation work as a form social enterprise was published in 1993. The scale and integration of co-operative development in the "red belt" of Italy (some 7000 worker, and 8000 social co-operatives) inspired the formation of the EMES network of social economy researchers who subsequently spread the language to the UK and the rest of Europe through influential English language publications. In the US, the work of Ashoka was picked up at Harvard, Stanford and Princeton universities, and each made contributions to the development of the field of social entrepreneurship through project initiatives and publications. Social enterprises are often regarded-erroneously_as non-profit organisations. Social enterprise is characterized by open membership and goals widely considered to be in the community or public interest. By comparison, non-profit status may include organizations with private membership. A useful perspective, created by social enterprise consultants across four continents after a review by Social Enterprise Europe, highlights three factors which frame the business philosophy of a social enterprise:

1) The extent to which it engages in ethical review of the goods and services it produces, and its production processes;

2) The extent to which it defines its social purpose(s), and evidences its social impact;

3) The extent to which it democratises ownership, management and governance by passing control of its human, social and financial capital to its primary stakeholders (producers, employees, customers, service users).

As an organized group, their international definition states:

"Not for Profit is a misleading criterion. It is good practice for social enterprises to provide incentives to workers, and social and community investors through dividends. Distribution of profits or payments to individuals should not compromise the enterprises’ value statement or social objectives” (ASWEA, 1982). The field of social enterprise studies has not yet developed firm philosophical foundations, but its advocates and academic community are much more engaged with critical pedagogies (e.g. Paulo Freire) and critical traditions in research (e.g. critical theory/institutional theory/Marxism) in comparison to private sector business education (Agouba, 1977: pp. 37-55). Teaching related to the social economy draws explicitly from the works of Robert Owen, Proudhon and Karl Marx with works by Bourdieu and Putnam informing the debate over social capital and its relationship to the competitive advantage of mutuals. This intellectual foundation, however, does not extend as strongly into the field of social entrepreneurship where there is more influence from writings on liberalism and entrepreneurship by Joseph Schumpeter, in conjunction with the emerging fields of social innovation, actor-network theory and complexity theory to explain its processes.

Social enterprise (unlike private enterprise) is not taught exclusively in a business school context, as it is increasingly connected to the health sector and public service delivery. The first international journal was established in 2005 by Social Enterprise London (with support from the London Development Association). The So- 
cial Enterprise Journal has been followed by the Journal of Social Entrepreneurship, and coverage of the issues pertaining to the social economy and social enterprise are also covered by the Journal of Co-operative Studies and the Annals of Co-operative and Public Economics. The European Social Enterprise Research Network (EMES) and the Co-operative Research Unit (CRU) at the Open University have also published research into social enterprise. The Skoll World Forum, organised jointly by Oxford and Duke universities, brings together researchers and practitioners from across the globe.

In 2009 Social Traders partnered with the Australian Centre for Philanthropy and Nonprofit Studies (ACPNS) at Queensland University of Technology to define social enterprise and, for the first time in Australia, to identify and map the social enterprise sector: its scope, its variety of forms, its reasons for trading, its financial dimensions, and the individuals and communities. The resulting definition views social enterprises as organisations that:

4) Are led by an economic, social, cultural, or environmental mission consistent with a public or community benefit;

5) Trade to fulfil their mission;

6) Derive a substantial portion of their income from trade; and

7) Reinvest the majority of their profit/surplus in the fulfilment of their mission.

The Social Enterprise Alliance (SEA: 1977) of the United States defines a "social enterprise" as "an organization or venture that advances its primary social or environmental mission using business methods". In the US, two distinct characteristics differentiate social enterprises from other types of businesses, nonprofits, and government agencies:

8) Social enterprises directly address social needs through their products and services or through the numbers of disadvantaged people they employ. This distinguishes them from "socially responsible businesses", which create positive social change indirectly through the practice of corporate social responsibility (e.g., creating and implementing a philanthropic foundation; paying equitable wages to their employees; using environmentally friendly raw materials; providing volunteers to help with community projects).

9) Social enterprises use earned revenue strategies to pursue a double or triple bottom line, either alone (as a social sector business, in either the private or the nonprofit sector) or as a significant part of a nonprofit's mixed revenue stream that also includes charitable contributions and public sector subsidies. This distinguishes them from traditional nonprofits, which rely primarily on philanthropic and government support. Canadian social enterprise characteristics vary by region and province in the ways they differentiate social enterprises from other types of businesses, not-for-profits, co-operatives and government agencies.

10) Social enterprises may directly address social needs through their products and services, the number of people they employ or the use of their financial surplus. This can distinguish them from "socially responsible for-profit businesses", which create positive social change indirectly through the practice of corporate social responsibility (e.g., creating and implementing a charitable foundation; paying fair wages to their employees; using environmentally friendly raw materials; providing volunteers to help with community projects).

11) Social enterprises may use earned revenue strategies to pursue a double or triple bottom line, either alone (as a social economy business, in either the private or the not-for-profit sector) or as a significant part of a not-for-profit corporation's mixed income stream that may include charitable contributions and public sector assistance. This distinguishes them from some traditional not-for-profit corporations, which may rely in whole or part on charitable and government support.

Significant regional differences in legislation, financing, support agencies and corporate structures can be seen across Canada as a result of different historical development paths in the social economy. Common regional characteristics can be seen in British Columbia, the Prairies, Ontario, Quebec and Atlantic Canada. In Malaysia-Social Enterprise Alliance Malaysia defines social enterprises as "organizations created to address social problems that use business models to sustain themselves financially. Social enterprises seek to create not only financial returns but also social returns to their beneficiaries.” Social Enterprise Alliance Malaysia regards social enterprises as businesses with a social focus, distinct from non-profit organisations. In Europe-The best established European research network in the field, EMES, works with a more articulated definition-a Weberian "ideal type" rather than a prescriptive definition — which relies on nine fuzzy criteria.

\subsection{Economic Criteria}

1) Continuous activity of the production and/or sale of goods and services (rather than predominantly advi- 
sory or grant-giving functions).

2) A high level of autonomy: social enterprises are created voluntarily by groups of citizens and are managed by them, and not directly or indirectly by public authorities or private companies, even if they may benefit from grants and donations. Their members have the right to participate ("voice") and to leave the organisation ("exit”).

3) A significant economic risk: the financial viability of social enterprises depends on the efforts of their members, who have the responsibility of ensuring adequate financial resources, unlike most public institutions.

4) Social enterprises' activities require a minimum number of paid workers, although, like traditional nonprofit organisations, social enterprises may combine financial and non-financial resources, voluntary and paid work.

Social criteria include but not limted to the condition that they must have 1) an explicit aim of community benefit: one of the principal aims of social enterprises is to serve the community or a specific group of people. To the same end, they also promote a sense of social responsibility at local level; 2) Enjoy citizen initiative: social enterprises are the result of collective dynamics involving people belonging to a community or to a group that shares a certain need or aim; 3) Decision making not based on capital ownership: this generally means the principle of "one member, one vote", or at least a voting power not based on capital shares; 4) Participatory character, involving those affected by the activity: the users of social enterprises' services are represented and participate in their structures and, finally, Limited distribution of profit: social enterprises include organisations that totally prohibit profit distribution as well as organisations such as co-operatives, which may distribute their profit only to a limited degree, thus avoiding profit maximising behavior (Wikipedia, 2014).

Despite, and sometimes in contradiction to, such academic work, the term social enterprise is being picked up and used in different ways in various European countries. For example, in the Czech Republic a working party stemming from the development partnerships in the EQUAL program agreed on the following distinctions (April 2008).

\subsection{Social Economy}

It is a complex of autonomous private activities realized by different types of organizations that have the aim to serve their members or local community first of all by doing business. The social economy is oriented on solving issues of unemployment, social coherence and local development. It is created and developed on the base of concept of triple bottom line-economic, social and environmental benefits. Social economy enables citizens to get involved actively in the regional development. Making profit/surplus is desirable, however is not a primary goal. Contingent profit is used in preference for development of activities of organization and for the needs of local community. Internal relations in the social enterprises are headed to the maximum involvement of members/employees in decision-making and self-management while external relations strengthen social capital. Legal form of social economy entities is not decisive-what is crucial is observing public benefit aims as listed in the articles. Subjects of the social economy are social enterprises and organizations supporting their work in the areas of education, consulting and financing.

\subsection{Social Entrepreneurship}

Social entrepreneurship develops independent business activities and is active on the market in order to solve issues of employment, social coherence and local development. Its activities support solidarity, social inclusion and growth of social capital mainly on local level with the maximum respect of sustainable development.

\subsection{Attempts at Definition of Social Enterprise}

Social enterprise means "a subject of social entrepreneurship”, i.e. legal entity or its part or a natural person which fulfils principles of the social enterprise; social enterprise must have appropriate trade license. The above mentioned definitions stem from the four basic principles which should be followed by all social enterprises. According to the existing legal system, they can function in a form of cooperatives, civic associations, public benefit associations, church legal entities, Ltd., stock companies and sole traders. Budgetary organizations and municipalities should not be social enterprises as they are not autonomous - they are parts of public administration. Social entrepreneurship is defined very broadly. Beside employment of the people disadvantaged at the la- 
bour market it also includes organizations providing public benefit services in the area of social inclusion and local development including environmental activities, individuals from the disadvantaged groups active in business and also complementary activities of NGOs destined to reinvest profit into the main public benefit activity of an organization.

In the UK the accepted Government-backed definition of social enterprise used by the UK social enterprise sector bodies such as Social Enterprise UK comes from the 2002 Department of Trade and Industry report "Social Enterprise: a strategy for success" report as: (Spreckley, 2011). A business with primarily social objectives whose surpluses are principally reinvested for that purpose. The original use of the term social enterprise was, however, first developed by Freer Spreckley in 1978, and later included in a publication called Social Audit-A Management Tool for Co-operative Working published in 1981 by Beechwood College. Traditionally, "capital hires labor" with the overriding emphasis on making a "profit" over and above any benefit either to the business itself or the workforce. Contrasted to this is the social enterprise where "labor hires capital" with the emphasis on social, environmental and financial benefit. Later on the three areas of social, environmental and financial benefits used for measuring social enterprise became known as the Triple Bottom Line.

Whereas conventional businesses distribute their profit among shareholders, in social enterprises the surplus tends to go towards one or more social aims which the business has-for example education for the poor, vocational training for disabled people, environmental issues or for animal rights. Social enterprises are distinct from charities (although charities are also increasingly looking at ways of maximising income from trading) and from private sector companies with policies on corporate social responsibility. An emerging view, however, is that social enterprise is a particular type of trading activity that sometimes gives rise to distinct organisation forms reflecting a commitment to social cause working with stakeholders from more than one sector of the economy. Three common characteristics of social enterprises as defined by Social Enterprise London are:

1) Enterprise orientation: They are directly involved in producing goods or providing services to a market. They seek to be viable trading organisations, with an operating surplus.

2) Social Aims: They have explicit social aims such as job creation, training or the provision of local services. They have ethical values including a commitment to local capacity building, and they are accountable to their members and the wider community for their social environmental and economic impact.

3) Social ownership: They are autonomous organisations with governance and ownership structures based on participation by stakeholder groups (users or clients, local community groups etc.) or by trustees. Profits are distributed as profit sharing to stakeholders or used for the benefit of the community.

\subsection{Community Interest Companies}

The UK has also developed a new legal form called the community interest company (CIC). CICs are a new type of limited company designed specifically for those wishing to operate for the benefit of the community rather than for the benefit of the owners of the company. This means that a CIC cannot be formed or used solely for the personal gain of a particular person, or group of people. In Africa, two examples are drawn from Nigeria and Ghana.

\subsubsection{Ghana}

The registered non-profit Trashy Bags was launched in 2007 in order to increase public awareness of Ghana's solid plastic waste problem and clean up sachets from the streets of Accra. This company buys waste from collectors. After washing and drying the sachets, it sews them into fashionable bags and other products which are then sold in Accra and exported to eight other countries around the world. The Trashy Bags Company has collected 20 million plastic sachets since its founding, and employs 60 machinists. MIG Live is a for profit Social Enterprise that designs, develops and markets products, services and solutions that provide global socio economic value (Brokensha \& Hodge, 1969). The enterprise focuses on education, health and youth unemployment issues. They are forming strategic partnerships with entrepreneurs, leaders, local and global organizations to understand and collaborate on developing their various offerings. The business is only 2 years old but is on a mission to leverage creativity, media and technology to provide socio economic value to the world (Drake, 1962).

\subsubsection{Nigeria}

The Centre for Peace-building and Poverty Reduction, University of Nigeria (CEPPER) model is a dynamic so- 
cial development-oriented social enterprises like others in Kenya such as the One Acre Fund, Nuru International and Alive \& Kicking and M-Pesa, which facilitated economic transactions via mobile phone with spaces with IT infrastructure such as internet connectivity and computer hardware. CEPPER, accredited by the United Nation's agencies, are known centres with peaceful models for achieving sustainable employment and development goals for indigenous Wawa peoples of Africa in Nigeria, Cameroon, Ghana and Cote Voire. In Nigerian many NGOs such as CEPPER use business models to improve the lives of people, mainly in rural areas of the country. CEPPER as a social enterprise plants trees with smallholder farmers and uses economies of scale to enable them to access high value markets for processed trees. It also runs climate change awareness projects to mitigate climate change in the semiarid areas of the middle Belt and the North East before the incidence of terroroism from Boko Haram compelled it to halt activities in those areas. CEPPER organizes rural women into weaving projects whereby women who would traditionally engage in weaving make products that are marketed in the capital cities of Enugu, Nsukka and Awka in Nigeria or sent through to overseas markets of Europe and America. In Nigeria, though social enterprise organizational models exist different forms, they are yet to reach that height as in Kenya where they could be used to achieve the social transformative goals of social entrepreneurship. As leveraged non-profit ventures what an organizational model is and how it operates have been well defined and elaborated upon (Wikipedia, 2014):

The entrepreneur sets up a non-profit organization to drive the adoption of an innovation that addresses a market or government failure. In doing so, the entrepreneur engages a cross section of society, including private and public organizations, to drive forward the innovation through a multiplier effect. Leveraged non-profit ventures continuously depend on outside philanthropic funding, but their longer term sustainability is often enhanced given that the partners have a vested interest in the continuation of the venture. The entrepreneur sets up a non-profit organization but the model includes some degree of cost-recovery through the sale of goods and services to a cross section of institutions, public and private, as well as to target population groups. Often, the entrepreneur sets up several legal entities to accommodate the earning of an income and the charitable expenditures in an optimal structure. To be able to sustain the transformation activities in full and address the needs of clients, who are often poor or marginalized from society, the entrepreneur must mobilize other sources of funding from the public and/or philanthropic sectors. Such funds can be in the form of grants or loans, and even quasi-equity. Social business ventures are considered as The entrepreneur sets up a for-profit entity or business to provide a social or ecological product or service. While profits are ideally generated, the main aim is not to maximize financial returns for shareholders but to grow the social venture and reach more people in need. Wealth accumulation is not a priority and profits are reinvested in the enterprise to fund expansion. The entrepreneur of a social business venture seeks investors who are interested in combining financial and social returns on their investments.

Seen as purely different from other social ventures, Human Capital and Non-profit Ventures are hybrid non-profit ventures meant to promote and increase the value of human capital, social capital and ethical capital in human society (Ani, 2013). Advantages of social enterprise have been documented as noted by Rodney Schwartz (Zambikes, 2011) of Clearly So who listed a number of advantages of the social enterprise as a business:

1) Ability to raise capital at below market rates due to the ethical investment industry;

2) Easier access to publicity;

3) Labor costs below average, "as staff seems willing to work for below market rates in support of the values of social enterprises."

Schwartz went further to describe social entrepreneurs as "extraordinarily innovative, deploying models that seem to derive results out of thin air."

\section{Old Assumptions, New Questions and New Paradigms: Assumptions That Should Be Questioned}

Here are three major self-limiting assumptions I've heard at forums, none of which was questioned by participants. At least nine more assumptions will be described later in this series:

1) While there are usually a few green social entrepreneurs (who tend to be owners of small-to-medium-sized companies with a green product) at every forum, most are not, as usually the social welfare side gets the empha- 
sis. But given the global environmental crisis, why aren’t all social entrepreneurs also green, at least to a degree, and urged to become even more so-even if their focus and passion are elsewhere? While social entrepreneurs' environmental loadings are probably light, they should be expected to do their parts, too. If not, they risk becoming part of the problem, particularly as they scale up. In an example which begged for deeper green engagement, an urban honeybee social entrepreneur received a deserved ovation from the audience for her work. But as bees are obviously critical to her supply chain, it would have been worth mentioning that they are severely threatened by colony collapse disorder, as well as her going further by trying to play a role as a citizenscientist (perhaps "entrepreneur-scientist") helping to research solutions to the problem. By contrast, the United Nations' SEED Initiative usually gets the social/environmental connection better, although their forums and those of social entrepreneurs' need to mingle.

2) Relatedly, "sustainability" tends to be used strictly in the financial sense, in the capacity of social entrepreneurs to be able to stay "in business," not in the Brundtland, triple bottom line, can-we-keep-going-the-waythat-we're-going sense at all. For example, Rajiv Shah, the USAID administrator, in discussing its Global Development Alliance initiative with business and NGOs, said, "We also keep sustainability in mind when we design our partnerships, meaning that we hope the private sector will continue the partnership activity after USAID funding ends." (However, this agency is not consistent in which use they mean.) This point is particularly important because it actually gets back to, but challenges, one of the field's early seminal metaphors: "Give a man a fish and you feed him for one day; teach him how to fish and you feed him for a lifetime.” The metaphor falls apart if the water body is fished-out or severely polluted. The metaphor could use an update.

3) With "social" in its name, the field less often equates innovation with just "technology-centric" ideas than do other fields, but it still tends to overlook needed changes in culture, organizations and individual behavior. While nothing is wrong with some emphasis on technology or ICT, this should not come at the expense of non-technology innovations, which are so important they are worth some additional, even out-of-the-box, discussion.

New ideas for innovation are also emerging to define and redefine the field of social entrepreneurship. Therefore it is correct to observe that "the opportunity and perhaps the drive to innovate, as well as the topically popular link to "social" in the title, may explain some of the excitement the field generates. However, the actual focal areas where innovation is applied are missing things. Here are some ideas. At forums there is always a lot of emphasis on networking, with significant time allotted for it. This is certainly in keeping with the times, and not inappropriate. But it also sends a message of where the priorities are. By contrast, NPR's “All Things Considered" reports an interesting, if unplanned, process innovation at a non-social entrepreneurship conference. A social scientist, Mary Daly, had models, theories and knew "what economics think," but did not know where to obtain the all-important data to test whether her hypothesis that those coming off welfare during President Clinton's "workfare" reform program actually were going on disability, where states could continue to get reimbursed. This would challenge what had been seen as a public policy success. The reporter, Chana Joffe-Walt, said, (Mary) was at a conference. Mary spotted a young guy in the corner, looking a little nervous. She struck up a conversation and the guy started to tell her what he did for a living”.

4) Social Entrepreneurship and Ability to Recognize Transformational Ideas: Adriana Herrera, chief executive of Fashioning Change, critiques one social entrepreneur, Toms Shoes, whose big idea is to donate one pair of shoes to poor children for each pair it sells as "not doing more to change the underlying problem" of poverty. Further, she states, "imagine the positive impact Toms could have if it were to use every decision in its supply chain to address the causes of poverty," including manufacturing. While Toms Shoes seems like a good social entrepreneur, Herrara is raising the bar. Meeting it would take more degrees of innovation.

Another idea would be to extend the usual emphasis on starting one organization (or program) and taking it to scale, to catalyzing change (albeit in smaller individual doses) via many other social entrepreneurs, and helping them by providing some of what they are lacking, even what they had not known they were missing. If an idea is really transformational, but doesn't necessarily look like anything that came before it, would it even be recognized? It almost goes against human nature. To try to guard against missing something really "new under the sun," it is important to make space for it. Conference organizers should send a message at the beginning of forums that as not all forms of social entrepreneurship have been invented yet; we need to be open to new types of it, kind of like a friendly alien who has assumed human form, but whose identity can be detected with patience and the right set of eyes. It would be nice, if futile, to try to chase down a conference organizer to talk substance (I know, I've tried) while their minds are focused on keeping the coffee coming. So, they could ask just before 
the end of conferences, "Did we miss anything really important today, something which might help push the state of the art of the social entrepreneurship field? Anyone?” Finally, I suggest adding to the list of skills or traits cited as important to practitioners (here, here, here and here), an ability to give some thought as to when innovation is called for, and when it isn't. I hope these observations are seen as signs of what the field has grown up around, and not determinative of where it must remain. We'll certainly provide more for willing practitioners to reflect upon in the next part of this series. We need to keep these innovators innovating!

\section{Societal Problems Define Social Work in Africa Factors Affecting Social Work Education and Practice}

Several key factors have challenged and influenced social work education and practice in Africa (Tesfaye, 1974). Some were responsible for molding social work education and practice in the early stages; others are responsible for shaping them as they currently exist. Africa is a vast continent. Many significant changes have occurred in recent years. This presentation attempts to summarize the broad events that have shaped social work education and practice across the continent, bearing in mind that there are important regional differences. These events, past and present, include:

1) The colonial legacy relating to the philosophy and practice of social welfare and social security;

2) Independence movements;

3) Community development and mass literacy movements;

4) Growing recognition that economic development cannot be divorced from social development;

5) The oil crisis of the 1980's;

6) Natural disasters;

7) Forced migration;

8) National family planning programs;

9) Structural Adjustment Programs (SAPS) and debt re-financing;

10) Political instability and political upheavals;

11) The dismantling of apartheid in South Africa;

12) The persistence and pernicious effects of poverty;

13) Rapid social change, population growth and industrial development.

To understand the impact of these events on social work education and practice, one must examine them within the context of traditional family, health, welfare and social security systems, Western transfers of technology, Western health, welfare and social security systems exported to Africa, and existing infrastructures. Given the time constraint, a few of these events will be selected for discussion. It should be noted from the outset that many institutions and individuals both in Africa and around the world made significant contributions to shaping social work education and practice in Africa (United Nations, 1969).

\section{Social Dimensions of Development and the Social Entrepreneur in the Millennium}

A Huge social work and social philosophy challenges exist in Africa of the new millennium and the social entrepreneur is being loaded with a lot expectations from the state, civil society and the communities in resolving them (Asamoah, 1994). These problems define the social mandate and woman-date of the emerging social entrepreneur in Africa. Nearly 40\% of the world's population has income insufficient to meet their needs, and most live in the Third World, including Africa (UNICEF, 1993). A basic reality for many countries in Africa, both before and after independence, is poverty. While much progress has been made in the past few decades leading to higher standards of living for many, the scale of poverty for others is unacceptable in the 20th century. The derivatives of poverty are many. These derivatives shape the agenda for social work education and practice in Africa. The following issues, then, determine the priorities that need to be set by social workers who hope to make a difference in the African context: illiteracy, malnutrition, inadequate shelter, poor health and disease, especially AIDS, infant mortality and maternal, ill health, unemployment forced migration, exploitation and inequalities social insecurity inadequate education, and urban drift (Organization of African Unity (OAU), 1985).

Part of the task of developing policies and programs to alleviate the suffering caused by the above is to counter the notion that improvement in the general welfare is a natural outcome of economic development and modernization of traditional social structures (Hardiman \& Midgley, 1982). Countries which are currently instituting 
programs that will mitigate the social costs of structural adjustment are an excellent case and point. Ghana (DuSautoy, 1958) beginning in 1987, is one case example.

\section{Conclusion}

Despite the litany of problems, there is reason to hope for a brighter future. Among the reasons for this are the willingness to learn from the mistakes of the past, the good will and concern of many political leaders, social and economic assistance from national and international treaties and policies, and the expertise and dedication of social development workers. Particularly promising are the efforts being made in South Africa to counteract the evil legacies of apartheid and the movement towards a more humane and just society. It should be noted that social work practice in many places in Africa is not only a challenge but physically dangerous, and perseverance under these circumstances deserves special recognition. Specific challenges for the future for social work education and practice include: developing mechanisms for reducing tribal rivalries collaboration and cooperation with international organizations and NGO's for the eradication of poverty and elimination of diseases and all forms of discrimination strengthening the family as a unit of development of skills in macro-practice continued examination of the cultural appropriateness of models of social work intervention developing more public support for the critical roles social welfare personnel play in the social and economic development process.

\section{References}

African Centre for Applied Research and Training in Social Development (ACARTSOD) (1983). Social Implications of the Lagos Plan of Action. Tripoli, Libya Jamahiriya.

Agouba, M. L. (1977). Africa. Social Realities and the Social Work Response: The Role of Schools of Social Work (pp. 3755). New York: International Association of Schools of Social Work.

Ani (2013). Social Work in Socio-Political Philosophy: An African Framework. CEPPER Press, Enugu.

Asamoah, Y. (1994). Challenges to Social Work around the World: Africa. Storrs: University of Connecticut, Center for International Social Work, Inaugural Conference, School of Social Work.

Association for Social Work Education in Africa (ASWEA) (1982). Survey of Curricula of Development Training. Addis Ababa: Institutions in Africa.

Brokensha, D., \& Hodge, P. (1969). Community Development in Ghana. San Francisco: Chandler.

Drake, St. C. (1962). Social Problems in West Africa. In St. C. Drake, \& P. T. Omari (Eds.), Social Work in West Africa. Accra: Ghana Publishing Corporation.

DuSautoy, P. (1958). Community Development in Ghana. London: Oxford University Press.

Hardiman, M., \& Midgley, J. (1982). The Social Dimensions of Development: Social Policy and Planning in the Third World. New York: Wiley.

Organization of African Unity (OAD) (1985). Africa's Priority Programme for Economic Recovery. 1986-1990. Geneva: United Nations Food and Agricultural Organization (FAO).

Polsky, M. (2013). 12 Areas Where Social Entrepreneurship Needs to Improve.

Spreckley, F. (2011). Social Enterprise Planning Toolkit. The Meaning of Social Entrepreneurship. Duke University’s Fuqua School of Business, Attempts to Define What Makes a Social Entrepreneur. See also "A Developed World: An Online Social Publication Featuring the Stories of Social Entrepreneurs from around the World".

UNICEF (1993). The State of the World's Children. New York.

United Nations (1969). Proceedings of the International Conference of Ministers Responsible for Social Welfare. UN Publication, Sales No. E69. IV. 4.

Wikipedia (2014). Social Enterpreunership.

Yunus, M., Moingeon, B., \& Lehmann-Ortega, L. (2010). Building Social Business Models: Lessons from the Grameen Experience. In M. Nyssens (Ed.), Social Enterprises in Europe: Between Market, Public Policies and Communities. London: Routledge. 